\title{
Microbial aetiology and diagnostic criteria of postpartum endometritis in Nairobi, Kenya
}

\author{
MARLEEN TEMMERMAN,${ }^{*} \dagger$ MARIE LAGA, $\dagger \|$ JACKONIA O NDINYA-ACHOLA, $\dagger$ \\ MARIA PARASKEVAS, $\S$ ROBERT C BRUNHAM $\ddagger$ FRANCIS A PLUMMER, $\ddagger$ \\ PETER PIOT $\|$
}

From the *Department of Obstetrics and Gynaecology, University Hospital, University of Brussels, Belgium; the $\dagger$ Department of Medical Microbiology, University of Nairobi, Kenya; the Departments of $\ddagger$ Medical Microbiology, and \$Pathology, University of Manitoba, Winnipeg, Manitoba, Canada; and the ||Department of Microbiology, Institute of Tropical Medicine, Antwerp, Belgium

SUMMARY Using a protected triple lumen device, Neisseria gonorrhoeae or Chlamydia trachomatis, or both, were isolated from the endometriums of five out of 35 women with clinical postpartum endometritis compared with none of a control group of 30 puerperal women without endometritis $(\mathrm{p}<0.05)$ in Nairobi, Kenya. These sexually transmitted agents were also found in 12 cervical specimens from women with and three without postpartum endometritis $(\mathrm{p}=0.04)$. Mycoplasma hominis and Ureaplasma urealyticum were equally isolated from the endometrium in both groups. Histology showed plasma cell infiltration in $6 / 25$ patients compared with $1 / 22$ controls $(p=0.06)$. A history of foul lochia $(p<0.01)$ and abdominal pain $(p=0.02)$ were associated with postpartum endometritis. Sexually transmitted agents appear to be major causes of puerperal upper genital tract infections in Nairobi.

Female infertility remains a major health problem world wide, especially in Africa where tubal obstruction among previously pregnant women is often noted.' For instance, Walton and Mati reported that female infertility occurs in Kenya more often in women who have had at least one pregnancy, and is usually due to tubal scarring. ${ }^{2}$ In a previous study we found that $20.3 \%$ of 1013 consecutively delivering women of lower socioeconomic strata in Nairobi developed postpartum endometritis, as defined by clinical criteria. ${ }^{3}$ The incidences of gonococcal and chlamydial infections in that population were $7 \%$ and $21 \%$, respectively. Postpartum pelvic infections may play a major part in the aetiology of secondary infertility because of scarred fallopian tubes. Ascending infections of the female genital tract with both sexually transmitted agents and the bacterial flora of the lower genital tract may readily occur during the postpartum period.

The aims of this pilot study were to assess the correlation between clinical criteria and microbial and

Address for reprints: $\operatorname{Dr} M$ Temmerman, Department of Microbiology, Institute of Tropical Medicine, Nationalestraat 155, 2000 Antwerp, Belgium

Accepted for publication 18 November 1987 histological findings in the diagnosis of postpartum endometritis, and to assess the role of different microorganisms in the aetiology of this infection.

\section{Patients, materials, and methods}

\section{PATIENT ASSESSMENT}

The 35 patients recruited to the study were a subsample of a prospective cohort study on the epidemiology of ophthalmia neonatorum. ${ }^{4}$ At enrolment, demographic and obstetric data were recorded on a standard form. During labour, cervical swabs were obtained for cultures for Neisseria gonorrhoeae and Chlamydia trachomatis. Mothers and neonates were discharged 24 hours after delivery. Only women who delivered vaginally were enrolled in the study. At the first postpartum follow up on day 7 to 9 , a standardised history of fever, abdominal pain, and the appearance of the lochia was obtained from each woman, and her temperature was taken sublingually. The lochia was defined as purulent if it was yellow or green in colour. The presence of uterine subinvolution and uterine or adnexal tenderness was assessed by bimanual examination. Clinical severity was scored by grading signs and symptoms on a scale from absent or normal to severe.

Postpartum endometritis was diagnosed if at least 
two of the following criteria were present: fever, foul lochia, uterine tenderness, or uterine subinvolution. Controls were 32 puerperal women with at most only one of the above criteria. They were drawn from women who presented themselves at the postpartum clinic on the same day as a patient. As all patients were examined between day 7 and day 9 after delivery, these data concern late postpartum endometritis.

\section{COLLECTION OF SPECIMENS}

An unlubricated speculum was used to expose the cervix. Specimens for the isolation of $N$ gonorrhoeae, C trachomatis, Mycoplasma hominis, Ureaplasma urealyticum, and group B streptococci were taken from the cervix. A vaginal swab was obtained for Gram smear microscopy and gas liquid chromatography. After cleaning the cervix with povidone iodine, endometrial culture specimens for the same microorganisms were obtained using a protected triple lumen device (uterine sampling device (USD) 10/23; Medi-tech, Watertown, USA), which contains a protected triple lumen brush with a protective polyethylene glycol plug. A single strip endometrial biopsy specimen was obtained transcervically using a Novak curette.

\section{MICROBIOLOGICAL, HISTOLOGICAL, AND \\ BIOCHEMICAL STUDIES}

Specimens for $N$ gonorrhoeae were inoculated direct on to modified Thayer-Martin medium and stored at room temperature until transported to the laboratory. Cultures were then incubated in humidified candle extinction jars and read at 24,48 , and 72 hours. $N$ gonorrhoeae was presumptively identified by colony morphology seen on Gram staining and by oxidase reactivity, and was later confirmed by the production of acid from glucose but not from maltose or lactose. Specimens for $C$ trachomatis isolation were cultured on cycloheximide treated McCoy cells and read 72 hours after iodine staining. $U$ urealyticum and $M$ hominis were cultured from vaginal swabs on New York City medium. Specimens were plated direct on sheep blood agar for the recovery of Streptococcus agalactiae. Vaginal samples were analysed for organic acids by gas liquid chromatography as described previously. ${ }^{6}$

Endometrial biopsy specimens were fixed in formalin, and sections were stained with haematoxylin and eosin and methyl green pyronine to show plasma cells. Histological examination of the biopsy specimens was performed blind regarding the clinical and microbiological findings. Endometritis was classified as mild, moderate, or severe for plasma cell infiltration. Only moderate and severe endometritis was taken into account for the data analysis. Insufficient endometrial material was collected from
Table 1 Characteristics of 35 women with postpartum endometritis and 30 control puerperal women

\begin{tabular}{lcc}
\hline & $\begin{array}{c}\text { Patients } \\
(n=35)\end{array}$ & $\begin{array}{c}\text { Controls } \\
(n=30)\end{array}$ \\
\hline Mean age (years) & 22 & 23 \\
No primiparous & 20 & 20 \\
No married & 28 & 22 \\
Mean gestational age (weeks) & 39 & 40 \\
Duration of labour (hours) & 10 & 12 \\
Duration of ROM R $^{*}$ (hours) & 3 & 3 \\
Birth weight (g) & 3167 & 3208 \\
No with perinatal complications & 3 & 3 \\
\hline
\end{tabular}

*Rupture of membranes.

nine women, and nine specimens were lost from follow up.

\section{STATISTICAL METHODS}

The $\chi^{2}$ test with Yates's correction and Fisher's exact test were used to compare sample proportions, and Student's $t$ test was used to compare sample means.

\section{Results}

During six weeks we recruited 35 women with postpartum endometritis and 30 control women. Table 1 shows the characteristics of patients and controls; there was no difference between the two populations regarding age, parity, marital status, gestational age, duration of labour, duration of rupture of membranes, birth weight, and perinatal complications.

Table 2 compares the histories of the patients with those of the controls. The differences were significant for foul lochia $(p=0.005)$ and abdominal pain $(p=$ 0.02 ).

Table 3 shows the microbiological findings. The sexually transmitted agents, $N$ gonorrhoeae and $C$ trachomatis, were isolated from the cervices of 12 patients compared with three controls $(p<0.05)$ and from the endometriums of five patients compared with none of the controls $(p<0.05)$. The isolation of $M$ hominis and $U$ urealyticum was similar from the cervices and the endometriums of patients and controls. Overall 11 women had an increased peak ratio of vaginal succinate to lactate of 0.4 or more and five had vaginal smears compatible with bacterial vaginosis

Table 2 History of puerperal women with or without postpartum endometritis during seven to nine days after delivery

\begin{tabular}{lccl}
\hline & $\begin{array}{l}\text { Patients } \\
(n=35)\end{array}$ & $\begin{array}{l}\text { Controls } \\
(n=30)\end{array}$ & Difference \\
\hline Fever & 7 & 1 & NS \\
Foul lochia & 20 & 6 & $\mathrm{p}=0.005$ \\
Abdominal pain & 27 & 14 & $\mathrm{p}=0.02$ \\
\hline
\end{tabular}


Table 3 Microbiological findings in puerperal women with or without postpartum endometritis

\begin{tabular}{lccc}
\hline & $\begin{array}{c}\text { Patients } \\
(n=35)\end{array}$ & $\begin{array}{l}\text { Controls } \\
(n=30)\end{array}$ & Difference \\
\hline $\begin{array}{l}\text { Neisseria gonorrhoeae } \\
\text { from: }\end{array}$ & & & \\
$\quad$ Cervix & $8 / 34$ & $2 / 30$ & $\mathrm{p}=0.052$ \\
$\quad$ Endometrium & $3 / 35$ & $0 / 30$ & $\mathrm{p}=0.15$ \\
$\begin{array}{l}\text { Chlamydia trachomatis } \\
\text { from: }\end{array}$ & & & \\
$\quad$ Cervix & $6 / 30$ & $2 / 29$ & $\mathrm{p}=0.24$ \\
$\quad$ Endometrium & $3 / 35$ & $0 / 30$ & $\mathrm{p}=0.15$ \\
$\quad$ & & & \\
$\begin{array}{l}N \text { gonorrhoeae } \text { and } \\
\text { C trachomatis from: }\end{array}$ & $12 / 35$ & $3 / 30$ & $\mathrm{p}=0.04$ \\
$\quad$ Cervix & $5 / 35$ & $0 / 30$ & $\mathrm{p}=0.04$ \\
$\quad$ Endometrium & $18 / 34$ & $20 / 29$ & $\mathrm{p}=0.09$ \\
$\begin{array}{l}\text { Mycoplasma hominis } \\
\text { Ureaplasma urealyticum }\end{array}$ & $24 / 31$ & $18 / 25$ & $\mathrm{p}=0.22$ \\
$\begin{array}{l}\text { Gas liquid chromatography } \\
\text { findings: }\end{array}$ & & & \\
$\quad$ Vaginal succinate:lactate & & & \\
$\quad$ ratio >0.4 & $4 / 25$ & $7 / 29$ & $\mathrm{p}=0.23$ \\
$\quad$ Clue cells & $1 / 32$ & $4 / 28$ & $\mathrm{p}=0.12$ \\
\hline
\end{tabular}

(containing clue cells). Group B streptococci were not isolated.

We performed adequate histological studies of endometrial biopsy specimens from 25 patients and 22 controls. Moderate or severe plasma cell infiltration was found in six of the patients and in one of the controls $(p=0.06)$. Plasma cell infiltration did not correlate with the isolation of micro-organisms from either the cervix or the endometrium. Only one woman who yielded $C$ trachomatis from the endometrium showed plasma cells on biopsy.

\section{Discussion}

The diagnosis of postpartum uterine infection is often uncertain due to the lack of sensitive and specific clinical criteria. Other methods have therefore been developed, such as endometrial sampling that avoids contamination with cervical flora. In this study the sexually transmitted agents, $N$ gonorrhoeae and $C$ trachomatis, were isolated from a third of the women with postpartum endometritis. They were only found in the endometriums of patients with clinical manifestations of endometritis, which suggests that they were the cause of the upper genital tract infection, assuming that contamination with cervical flora was avoided by using a protected triple lumen device. It has been shown previously that uterine cultures obtained through the cervical canal do not enable the investigator to distinguish between infected and non-infected patients because of contamination..$^{78}$ Organisms were thus isolated from the endometrium in equal proportions from febrile and afebrile puerperal women, using an unprotected $\mathrm{swab}^{9}$ or a Milex canula. ${ }^{8}$

Cervical contamination was reduced by Pezzlo et al using a double lumen protected swab, ${ }^{10}$ and by Eschenbach, who isolated organisms from six $(43 \%)$ out of 14 afebrile women without clinical endometritis compared with 51 out of $55(93 \%)$ febrile postpartum women, using an open ended triple lumen device." Knuppel et al described a double lumen protected brush with a protective polyethylene glycol plug, with which they recovered organisms from the endometriums of $12(57 \%)$ out of 21 afebrile women. ${ }^{12}$ Organisms have also been isolated from the postpartum endometrium by transfundal sampling methods, ${ }^{11314}$ which may underestimate the problem because of the difficulty of ensuring that the aspiration needle enters the cavity. Culdocentesis has been used by Platt $e t$ al, who found anaerobes in the cul-de-sac in $87 \%$ of women with postpartum endometritis. ${ }^{15}$ Vaginal contamination, however, is difficult to exclude using this technique. Using a triple lumen polyethylene glycol plug protected brush we did not isolate gonococci or chlamydiae from the endometriums of women in the control group, including the three who yielded positive cervical cultures, which suggests a low contamination rate. Both organisms have been associated with postpartum endometritis. ${ }^{3516}$

In contrast, $M$ hominis and $U$ urealyticum were isolated equally from the cervices and endometriums of both groups, which suggests that these low virulence organisms may asymptomatically colonise the postpartum endometrium. These data accord with the findings of others. ${ }^{1113}$ Firm conclusions cannot be drawn from our data on genital mycoplasmas, however, as we did not undertake quantitative cultures. Both species of mycoplasma have been isolated from the blood of women with mild postpartum fever, ${ }^{1718}$ which suggests that these micro-organisms play a part in the aetiology of this condition.

The histological criteria used to define postpartum endometritis are based on plasma cell infiltration. Data on the histology of the postpartum uterus are scarce. Paavonen et al reported that $C$ trachomatis and $N$ gonorrhoeae in the endometriums of patients with acute pelvic inflammatory disease were associated with lymphoid follicles and the density of plasma cells on biopsy. ${ }^{19}$ In the present study severe plasma cell infiltration was found in $24 \%$ of patients compared with $5 \%$ of the controls $(p=0.06)$, but there was no correlation between microbiology and histology. This may be due to the small number of patients and to insufficient material, as a single strip biopsy specimen contains only a small portion of endometrial tissue.

We wish to emphasise the fact that in this study a third of the cases of postpartum endometritis were due to sexually transmitted diseases (STDs), whereas the 
aetiology of the remaining cases was not known. The control of maternal STDs may have a major impact on postpartum pelvic infections and secondary infertility.

Further prospective studies of a larger population are under way to elucidate the clinical and histological manifestations of postpartum endometritis in conjuction with a comprehensive study of the endometrial flora.

This study was supported by grants from the Programme on Science and Technology for Development, Commission of European Communities, the International Development Research Centre, Ottawa, Canada, and the National Foundation for Scientific Research (NFWO), Brussels.

\section{References}

1 Belsey MA. The epidemiology of infertility: a review with particular reference to sub-Saharan Africa. Bull WHO 1976;54:319-41.

2 Walton SM, Mati JKG. An evaluation of secondary infertility in Kenya. East Afr Med J 1976;53:310-4.

3 Plummer FA, Laga M. Postpartum upper genital tract infections in Nairobi: epidemiology, etiology and risk factors. J Infect Dis 1987;156:92-8.

4 Laga M, Plummer FA, Nsanze $H$, et al. Epidemiology of ophthalmia neonatorum in Kenya. Lancet 1986 ;ii:1145-8.

5 Wager GP, Martin DH, Koutsky L, et al. Puerperal infectious morbidity: relationship to route of delivery and to antepartum Chlamydia trachomatis infection. Am J Obstet Gynecol 1980;138:1028-33.

6 Piot P, Van Dyck E, Godts P, Vanderheyden J. The vaginal microbial flora in non-specific vaginitis. Eur J Clin Microbiol 1982;1:301-6.

7 Mishell DR Jr, Moyer DL. Association of pelvic inflammatory disease with the intrauterine device. Clin Obstet Gynecol 1969;12:179-97.

8 Gibbs RS, O'Dell TN, MacGregor RR, Schwarz RH, Morton H. Puerperal endometritis. A prospective microbiologic study. $\mathbf{A m}$ J Obstet Gynecol 1975;121:919-25.

9 Hite KE, Hesseltine HC, Goldstein L. A study of bacterial flora of normal and pathologic vagina and uterus. Am J Obstet Gynecol 1947;53:233-40.

10 Pezzlo MT, Hesser JW, Morgan T, Valter PJ. Improved laboratory efficiency and diagnostic accuracy with new doublelumen-protected swab for endometrial specimens. $J$ Clin Microbiol 1979;9:56-9.

11 Eschenbach DA. Endometrial cultures obtained by a triple lumen method from afebrile and febrile postpartum women. $J$ Infect Dis 1986;153:1038-45.

12 Knuppel RA, Scerbo JC, Dzink J, Mitchell GW Jr, Cetrulo CL, Bartlett J. Quantitative transcervical uterine cultures with a new device. Obstet Gynecol 1981;57:243-8.

13 Ledger WJ, Gee CL, Pollin PA, Lewis WP, Sutter VL, Finegold SM. A new approach to patients with suspected anaerobic postpartum pelvic infections. Transabdominal uterine aspiration for culture and metronidazole for treatment. Am J Obstet Gynecol 1976;126:1-6.

14 Spore WW, Moskal PA, Nakamura RM, Mishell DR. Bacteriology of postpartum oviducts and endometrium. Am J Obstet Gynecol 1970;107:572-7.

15 Platt LD, Yonekuwa ML, Ledger WL. The role of anaerobic bacteria in postpartum endomyometritis. Am J Obstet Gynecol 1979;135:814-7.

16 Hoyme VB, Kiviat N, Eschenbach DA. Microbiology and treatment of late postpartum endometritis. Obstet Gynecol 1986;68:226-32.

17 McCormack WM, Lee YH, Lin JS, et al. Genital mycoplasmas in postpartum fever. J Infect Dis 1973;127:193-6.

18 Wallace RJ Jr, Alpert S, Browne K, Lin JS, McCormack WM. Isolation of Mycoplasma hominis from blood cultures in patients with postpartum fever. Obstet Gynecol 1978;51:181-5.

19 Paavonen J, Teisala K, Heinonen RK, et al. Microbiological and histopathological findings in acute pelvic inflammatory disease. Br J Obstet Gynaecol 1987;94:454-60. 